University of Nebraska - Lincoln

DigitalCommons@University of Nebraska - Lincoln

7-18-2003

\title{
Ascaris suum: cDNA microarray analysis of 4th stage larvae (L4) during self-cure from the intestine
}

Motoko Morimoto

Dante Zarlenga

Hunter Beard

Nadim Alkharouf

Benjamin F. Matthews

See next page for additional authors

Follow this and additional works at: https://digitalcommons.unl.edu/usdaarsfacpub

This Article is brought to you for free and open access by the U.S. Department of Agriculture: Agricultural Research Service, Lincoln, Nebraska at DigitalCommons@University of Nebraska - Lincoln. It has been accepted for inclusion in Publications from USDA-ARS / UNL Faculty by an authorized administrator of DigitalCommons@University of Nebraska - Lincoln. 
Authors

Motoko Morimoto, Dante Zarlenga, Hunter Beard, Nadim Alkharouf, Benjamin F. Matthews, and Joseph F. Urban Jr. 


\title{
Ascaris suum: cDNA microarray analysis of 4th stage larvae (L4) during self-cure from the intestine
}

\author{
Motoko Morimoto, ${ }^{\mathrm{a}}$ Dante Zarlenga, ${ }^{\mathrm{b}}$ Hunter Beard, ${ }^{\mathrm{c}}$ Nadim Alkharouf, \\ Benjamin F. Matthews, ${ }^{c}$ and Joseph F. Urban Jr. ${ }^{\text {a,* }}$ \\ ${ }^{a}$ United States Department of Agriculture, Agricultural Research Service, Nutrient Requirements and Functions Laboratory, \\ Beltsville Human Nutrition Research Center, Beltsville, MD 20705, USA \\ ${ }^{\mathrm{b}}$ Immunology and Disease Resistance Laboratory, Animal and Natural Resources Institute, Beltsville, MD 20705, USA \\ ${ }^{\mathrm{c}}$ Soybean Genomics and Improvement Laboratory, Plant Sciences Institute, Beltsville, MD 20705, USA
}

Received 12 September 2002; received in revised form 2 June 2003; accepted 18 July 2003

\begin{abstract}
There is spontaneous cure of a large portion of Ascaris suum 4th-stage larvae (L4) from the jejunum of infected pigs between 14 and 21 days after inoculation (DAI). Those L4 that remain in the jejunum continue to develop while those that have moved to the ileum are eventually expelled from the intestines. Although increases in intestinal mucosal mast cells and changes in local host immunity are coincidental with spontaneous cure, the population of L4 that continue to develop in the jejunum may counteract host protective mechanisms by the differential production of factors related to parasitism. To this end, a cDNA library was constructed from L4 isolated from pig jejunum at 21 DAI, and 93\% of 1920 original clones containing a single amplicon in the range 400 $1500 \mathrm{bp}$ were verified by gel electrophoresis and printed onto glass slides for microarray analysis. Fluorescent probes were prepared from total RNA isolated from: (1) 3rd stage-larvae from lung at 7 DAI, (L3); (2) L4 from jejunum at 14 DAI (L4-14-J); (3) L4 from jejunum at 21 DAI (L4-21-J); (4) L4 from ileum at 21 DAI (L4-21-I, and; (5) adults (L5). Cy3-labeled L3, L4-14-J, L4-21-I and L5 cDNA, and Cy5-labeled L4-21-J cDNA were simultaneously used to screen the printed arrays containing the L4-21-J-derived cDNA library. Several clones showed consistent differential gene expression over two separate experiments and were grouped into 3 distinct transcription patterns. The data showed that sequences from muscle actin and myosin, ribosomal protein L11, glyceraldehyde-3phosphate dehydrogenase and the flavoprotein subunit of succinate dehydrogenase were highly expressed in L4-21-J, but not in L421-I; as were a collection of un-annotated genes derived from a worm body wall-hypodermis library, and a testes germinal zone tissue library. These results suggest that only actively developing A. suum L4 are destined to parasitize the host and successfully neutralize host protective responses.

(C) 2003 Published by Elsevier Inc.

Index Descriptors and Abbreviations: Nematoda; Ascaridoidea; PCR, polymerase chain reaction; RNA, ribonucleic acid; cDNA, complementary deoxyribonucleic acid; SDS, sodium dodecyl sulphate; SSC, saline sodium citrate buffer; TE, Tris:EDTA buffer; PMT, photomultiplier tubes; BLAST, Basic Local Alignment Search Tool; EST, expressed sequence tag; DAI, days after inoculation; L3, A. suum 3rd stage-larvae L4-14-J, 4th stage-larvae from the jejunum at 14 DAI ; L4-21-J, 4th stage-larvae from the jejunum at 21 DAI; L4-21-I, 4th stage-larvae from the ileum at 21 DAI; L5, 5th stage-larvae or young adult; Cy3, cyber green 3; Cy5, cyber red 5; MMC, mucosal mast cell; Th2, T helper cell 2; G3PDH, glyceraldehyde-3phosphate dehydrogenase; bp, base pairs
\end{abstract}

\section{Introduction}

Ascaris suum is the most ubiquitous nematode parasite of swine, while Ascaris lumbricoides continues as a major worldwide human health problem, especially of children (Chan, 1997). Large intestinal roundworms are

\footnotetext{
${ }^{*}$ Corresponding author. Fax: 1-301-504-9062.

E-mail address: urban@307.bhnrc.usda.gov (J.F. Urban Jr.).
}

usually discovered in young feeder pigs. These worms effect weight gain due to a drop in feed intake and metabolic efficiency and may contribute to secondary microbial disease (Roepstorff and Nansen, 1998; Urban, 1993). Pigs are infected by ingesting eggs containing 2 nd stage larvae (L2) (Douvres et al., 1969) and/or 3rd stage larvae (L3) (Fagerholm et al., 2000) that hatch, penetrate the cecum (Murrell et al., 1997) and migrate to the liver within $8-18 \mathrm{~h}$ of infection (Douvres et al., 1969). 
The L3 migrate from the liver to the lungs between 4 and 6 days after infection (DAI) (Douvres et al., 1969), develop to late L3 that migrate to the small intestine between 8 and 10 DAI (Douvres et al., 1969) and then to the 4th stage larvae (L4) that develop shortly after arriving in the jejunum. The L5 (young adult) appear between 23 and 25 DAI and become fecund adults after day 43 (Pilitt et al., 1981).

Larval migration causes several clinical symptoms including hemorrhagic lesions in the lung with intense infiltration of eosinophils around alveoli, and inflammatory reactions in the liver that cause intralobular tissue fibrosis and hemorrhage that appear as "white spots." Protective immunity to larval migration of $A$. suum is expressed as reduced white spots in the liver and lower recovery of L3 from lungs after a challenge infection (Eriksen et al., 1992; Urban et al., 1988). There is also a spontaneous cure of L4 between 14 to 21 DAI as the number of L4 in the jejunum is displaced to the ileum by $>90 \%$ (Roepstorff et al., 1997). Mucosal mast cells (MMC) are elevated in the small intestine and release histamine after exposure to the $A$. suum L3 and L4 antigens coincidentally with the expulsion process (Ashraf et al., 1988). In general, worm expulsion from the intestines is a component of immune and physiological changes that are largely induced by Th2-derived cytokines to evoke a "weep and sweep" response characterized by intestinal smooth muscle contractility, reduced glucose uptake, and increased fluid accumulation in the lumen that alters the microenvironment and forces worms from their predilection site (Finkelman et al., 1997; Madden et al., 2002; Shea-Donohue et al., 2001). Although changes in the intestinal milieu are induced by host immunity, differential gene expression by L 4 could also contribute to an active regulation of intestinal parasitism.

Microarray analysis is a powerful technology that simultaneously monitors expression of thousands of genes. This method has been used to evaluate the genetic component of host immunity to infectious disease (Bigger et al., 2001; Chang and Laimins, 2000; Geiss et al., 2000). It can provide useful information to target genes that play an important role in complex disease conditions like the interaction between a host and a tissue migratory metazoan parasite. In this study, we characterized gene expression patterns of $\mathrm{L} 4$ from the jejunum at 21 DAI, a larval population destined to survive to the adult stage, to identify potential targets for enhanced control of this infection.

\section{Materials and methods}

\subsection{Animals and worm infection and isolation}

Crossbred Yorkshire $\times$ Polland-China pigs (males and females) were born and maintained at the Beltsville
Agricultural Research Center swine facility under management conditions that preclude exposure to helminth parasites. Pigs were weaned at 3-5 weeks of age and put on study between 8 and 12 weeks of age. The acquisition and preparation of infective A. suum eggs, oral inoculation of pigs and their management, and recovery of live L3 from the lungs of infected pigs at 7 DAI have been described (Urban and Romanowski, 1985). Recovery of live L4 from the jejunum at 14 DAI (L4-14-J), from jejunum at 21 DAI (L4-21-J), and from ileum at 21 DAI (L4-21-I) was performed by a modification of methods described by Slotved et al. (1997). Briefly, the small intestine was removed from the pyloric sphincter to the ileal/cecal junction and divided into 6 equal sections from anterior to the posterior end that were tied to prevent movement of contents in the lumen. The sections were opened and the contents collected in a bucket. The mucosal side of the intestine was pressed between two fingers to remove material that was loosely associated with the mucosal surface. An equal volume of molten $2 \%$ agarose (Fisher Brand) at $40^{\circ} \mathrm{C}$ was added to the suspension and then quickly poured into a stainless steel tray containing a layer of cheesecloth and maintained at room temperature for $20 \mathrm{~min}$. The gel-impregnated cheesecloth was then suspended into a container filled with $0.85 \% \mathrm{NaCl}$ (saline) at $37{ }^{\circ} \mathrm{C}$ for $2 \mathrm{~h}$. Larvae that migrated from the agar settled to the bottom of the container and were isolated by decanting. Settling of the larvae followed by decanting of the supernatant was continued in cone-shaped glasses until the suspension was clear. This provided a suspension of actively moving larvae that were free of host material. The L4 collected in the second and third most anterior region of the small intestine were considered as L4 from the jejunum while those from the most posterior section were termed L4 from the ileum. The L5 (adult worms) were obtained from locally infected pigs by screening intestinal contents of the jejunum.

\subsection{Preparation of $L 4 c D N A$ library}

Total RNA was extracted from L4-21-J using Trizol (Life Technologies). mRNA was isolated with the mRNA Separator kit (Clontech, \#K1040-2), and an oligo(dT)-primed cDNA library was constructed in the plasmid pSPORT1 by directional cloning using NotI/ SalI adaptors (Life Technologies, \#18248-013). The cDNA was used to transform ElectroMAX Escherichia coli DH10B cells (Life Technologies, \#18290-15) according to the manufacture's instructions.

\subsection{Preparation of $P C R$ products}

A total of 1920 clones were picked and cultured overnight in 96 well plates. Five micro-liters of culture suspension from each well were transferred into 96 well 
PCR plates and the cloned inserts were amplified in $50 \mu 1$ PCR reactions using M13 forward and reverse primers, and Ex-Taq DNA polymerase (Takara, \#RR001A). Following a 10 min denaturation step at $94{ }^{\circ} \mathrm{C}$, amplification proceeded for 35 cycles consisting of $1 \mathrm{~min}$ at $94^{\circ} \mathrm{C}, 1 \mathrm{~min}$ at $55^{\circ} \mathrm{C}$, and $2 \mathrm{~min}$ at $72^{\circ} \mathrm{C}$. The PCR reactions were terminated with a $7 \mathrm{~min}$ final extension at $72^{\circ} \mathrm{C}$. Products were verified by gel electrophoresis and stored for future use in 96 well $\mathrm{V}$ bottom plates (Corning Coaster, \#3363). PCR products were precipitated by the addition of ammonium acetate to a final concentration of $2.5 \mathrm{M}$ and 1 volume of isopropanol followed by overnight incubation at $-20^{\circ} \mathrm{C}$. The next day, the plates were centrifuged $(3.4 g)$ for $45 \mathrm{~min}$, and the pellets washed with $70 \%$ EtOH. All samples were air-dried and resuspended in $5 \mu \mathrm{l}$ of $50 \%$ DMSO- $50 \%$ TE buffer before printing onto glass slides.

\subsection{Printing slides for hybridization}

PCR products were printed in triplicate on glass slides (Corning, CMT GAPs, \#2550) with a robotic arrayer (Cartesian, PixSys 5500) (Hegde et al., 2000). Three cDNAs from alfalfa weevil, cow and human were printed at concentrations of $500,250,100,50$, and $25 \mu \mathrm{g} /$ $\mathrm{ml}$ to serve as internal controls and to assess for labeling and detection efficiency. The slides were air-dried and the spotted cDNA was bound to slides by UV-crosslinking at $250 \mathrm{~mJ}$ using UV Stratalinker 2400 (Stratagene) (Quackenbush, personal communication). Printed slides were stored in a desiccator at room temperature until needed.

\subsection{RNA labeling and hybridization}

Fluorescent probes were prepared from total RNA that was isolated from L3, L4-14-J, L4-21-J, L4-21-I, and L5. Total RNA from each stage was labeled using Cy3 or Cy5-dUTP (NEN, \#s NEL578001EA, NEL579001EA) (Hegde et al., 2000). Briefly, the reverse transcription reaction was carried out in a $30 \mu$ volume containing $10 \mu \mathrm{g}$ of total RNA, $2 \mu \mathrm{g}$ oligo(dT) 12-18 mer (Amersham-Pharmacia, Arlington Heights, Illinois), $500 \mu \mathrm{M}$ each of dATP, dCTP, dGTP, $100 \mu \mathrm{M}$ dTTP, $100 \mu \mathrm{M}$ of Cy3 dUTP or Cy5 dUTP (NEN, Life Science Products, Boston, MA), $0.5 \mathrm{mM}$ DTT (Life Technologies, Carlsbad, CA), and 400 U SuperScript II reverse transcriptase (Life Technologies) in $1 \times$ SuperScript first-strand buffer. Three specific control Poly(A) ${ }^{+}$RNAs (pml-72; GMC1, 2 and 3; Sp3) corresponding to coding sequences from alfalfa weevil, cow and human DNA respectively, were synthesized by in vitro transcription (Epicenter, Madison, WI) followed by oligotex-dT resin (Qiagen, Valencia, CA) purification. To serve as quantitative controls, the RNAs were added to the reverse transcription reaction at a mass ratio of $1: 1000,1: 10,000$, and $1: 100,000$ (wt/wt), respectively. After incubation for $2 \mathrm{~h}$ at $42^{\circ} \mathrm{C}$, the RNA was degraded by adding $1.5 \mu \mathrm{l}$ of $0.5 \mathrm{~N} \mathrm{NaOH}$ followed by 10 -min incubation at $70^{\circ} \mathrm{C}$. The samples were neutralized by addition of $1.5 \mu \mathrm{l}$ of $0.5 \mathrm{~N} \mathrm{HCl}$. The probes were purified using a ProbeQuantTM G-50 Micro Columns (Pharmacia Cat\# 27-5335-01) followed by two sequential ethanol precipitations in the presence of $2.5 \mathrm{M}$ ammonium acetate. Pellets were washed once with $70 \%$ ethanol, dried, and re-suspended in $10 \mu \mathrm{l}$ filtersterilized TE ( $\mathrm{pH} 8.0)$. The $\mathrm{Cy} 3$ and $\mathrm{Cy} 5$ labeled samples (10 $\mu \mathrm{l}$ each) were combined, and $10 \mu \mathrm{g}$ each of human Cot-1 DNA (Life Technologies) and Poly(dA) (Amersham-Pharmacia) were added. The probes were prepared for hybridization by heating at $95^{\circ} \mathrm{C}$ for $3 \mathrm{~min}$, centrifuging at $20,000 \mathrm{~g}$ for $1 \mathrm{~min}$, and transferring to one volume of $2 \times$ hybridization buffer ( $50 \%$ formamide, $10 \times \mathrm{SSC}, 0.2 \% \mathrm{SDS}$ ) pre-warmed to $42^{\circ} \mathrm{C}$. The slides were washed in $0.1 \%$ SDS solution for $10 \mathrm{~min}$ at room temperature, then pre-hybridized in $5 \times \mathrm{SSC}, 1 \% \mathrm{BSA}$, and $0.1 \%$ SDS at $42{ }^{\circ} \mathrm{C}$ for $45 \mathrm{~min}$. All pre-hybridizations and all pre- and post-hybridization washes were carried out in glass Coplin racks and jars. Slide prehybridization was followed by two washes in filtered water and one wash in 100\% 2-propanol. Drying was done by a centrifugation at $45 \mathrm{~g}$ for $1 \mathrm{~s}$. The probe mixture was then applied onto the microarray surface and covered with cover slips (Grace Biolabs, Bend, OR). Arrays were transferred to a hybridization chamber (Corning) and incubated for $18-20 \mathrm{~h}$ at $42{ }^{\circ} \mathrm{C}$ in a water bath. High humidity is maintained in the hybridization chamber; however, testing in a dry incubator can be used as an alternative procedure. The arrays were washed in five solutions according to the following schedule: $1 \times \operatorname{SSC}-0.2 \%$ SDS at $42{ }^{\circ} \mathrm{C}$ for $1 \mathrm{~min}, 1 \times$ $\mathrm{SSC}-0.2 \% \mathrm{SDS}$ at $42^{\circ} \mathrm{C}$ for $4 \mathrm{~min}, 0.1 \times \mathrm{SSC}-0.2 \%$ SDS at $25^{\circ} \mathrm{C}$ (room temperature) for $4 \mathrm{~min}, 0.1 \times \mathrm{SSC}$ at $25^{\circ} \mathrm{C}$ for $1 \mathrm{~min}$, and $0.1 \times \mathrm{SSC}$ at $25^{\circ} \mathrm{C}$ for $2 \mathrm{~min}$. They were dried by centrifugation at $45 \mathrm{~g}(600 \mathrm{rpm})$ for $1 \mathrm{~min}$ and scanned for each fluor at a resolution of $10 \mu \mathrm{m}$ with a photomultiplier tube (PMT) and laser power set the optimal value, using a ScanArray 4000 (GSI Lumonics, Meriden, CT). This preliminary scan was used to determine an optimal laser power voltage and PMT voltage for the most intense spot in the array for each fluor. Pre-hybridization and hybridization conditions were repeated to confirm the data.

\subsection{Microarray data analysis}

Fluorescence intensities were determined using the extraction and analysis software, SPOT, that is available at http://www.cmis.csiro.au/iap/spot.htm. The final fluorescence ratios were calculated using averaged data from the labeling of three cDNA preparations and subsequent hybridizations, derived from two 
independent sets of experiments. The larval collections were pooled from 3 to 5 infected pigs and RNA was isolated from approximately 30,000 L3; 5000 L4-14-J; 100 L4-21-J; and 200 L4-21-I and 6 adults. The spots with either printing or hybridization artifacts were flagged and discarded before analysis. Only spots with an intensity of at least two-times above the local background in both channels were used for subsequent analysis. This filtering process usually removed $5-15 \%$ of the elements, the percentage of which varied from slide to slide. The extracted data from each slide was then normalized in log space with a concentration gradient of alfalfa weevil positive control that was printed in various locations on the slide. Three replicates for each clone were printed on each slide, and each slide was replicated three times. This was done to account for the inherent variability in cDNA microarrays within and across slides. Generally, small variability was found within microarray slides with the three replicates for each clone having low standard deviations. Across the slide variability was greater, but only clones that exhibited similar expression patterns across all slide replications were selected for further analysis. These clones were determined by querying our expression database to select for clones with similar expressions across all three slides and by the use of One Way Analysis of Variance (ANOVA) tests to compare the mean expression ratio of clones across replicated slides. A total of 17 clones selected by these criteria are shown in Table 1 and Fig. 2.

Genes that had large absolute $t$ statistics values and positive average expression levels were differentially induced genes, while genes that had large absolute $t$ statistic values but negative average expression levels were identified as differentially suppressed genes. A relational database was constructed using SQLServer2000 for the storage, analysis and comparison of microarray data for this experiment. SQL procedures and other in-house tools were developed for statistical analysis without resorting to third party software. The database, the raw and normalized data for each slide, and the tools developed to analyze and compare the data are available on the World Wide Web at http://bldg6.arsusda.gov/ benlab/. The slides were scanned in both $\mathrm{Cy} 3$ and $\mathrm{Cy} 5$ channels with a Scan Array 4000 (GSI Lumonics, \#9003011523000). ScanAlyze (Stanford University) was used for image analysis. Reciprocal dye pairings were con-

Table 1

Transcriptionally active genes from A. suum L4 identified by a BLAST and C. elegans protein database searches

\begin{tabular}{|c|c|c|c|}
\hline Clone \# & BLAST search (DNA) Accession \#; homologue & $\begin{array}{l}\text { DNA } \\
\text { similarity }(\%)\end{array}$ & $\begin{array}{l}\text { Caenorhabditis elegans (protein) } \\
\text { Accession \#; } \mathrm{aa}^{\mathrm{b}} \text { similarity }\end{array}$ \\
\hline \multicolumn{4}{|l|}{ Profile $A$} \\
\hline $3 \mathrm{H} 08$ & Onchocerca volvulus $\mathrm{L}^{\mathrm{a}}$ & 68 & $\begin{array}{l}\text { CE02761; 41/100 } \mathrm{aa}^{\mathrm{b}} \\
\text { Troponin T-like protein }\end{array}$ \\
\hline $3 \mathrm{C} 03$ & Ascaris suum & 98 & CE28042; 59/62 aa \\
\hline & CB013935; ribosomal protein L11 & & Ribosomal protein L11 \\
\hline $3 \mathrm{a} 01$ & $\begin{array}{l}\text { Ascaris suum } \\
\mathrm{AB} 058666 ; \mathrm{G} 3 \mathrm{PDH}\end{array}$ & 99 & $\begin{array}{l}\text { CE02343; 44/54 aa } \\
\text { G3PDH }\end{array}$ \\
\hline $2 \mathrm{~b} 10$ & Ascaris suum ovary, adult female gut, adult male head, embryo ${ }^{a}$ & 98 & $\mathrm{ND}^{\mathrm{c}}$ \\
\hline $13 \mathrm{~h} 11$ & $\begin{array}{l}\text { Ascaris suum } \\
\text { AB071995; succinate dehydrogenase flavoprotein subunit }\end{array}$ & 98 & $\begin{array}{l}\text { CE16895; 73/88 aa } \\
\text { Succinate dehydrogenase }\end{array}$ \\
\hline $11 \mathrm{a} 03$ & Ascaris suum L4 only; abundant sequence ${ }^{\mathrm{a}}$ & 99 & ND \\
\hline $8 \mathrm{a} 08$ & Ascaris suum body wall-hypodermis, A. lumbricoides adult male ${ }^{\mathrm{a}}$ & 97 & $\begin{array}{l}\text { CE07185; } 21 / 23 \text { aa cuticle } \\
\text { collagen (putative) }\end{array}$ \\
\hline 7Е03 & $\begin{array}{l}\text { Ascaris suum adult male/female head, muscle-nerve cord, adult } \\
\text { female gut, embryo }\end{array}$ & 97 & ND \\
\hline \multicolumn{4}{|l|}{ Profile $B$} \\
\hline 13h08/B & Ascaris suum body wall-hypodermis, (putative nematode collagen) ${ }^{\mathrm{a}}$ & 93 & ND \\
\hline $2 \mathrm{a} 11 / \mathrm{B}$ & Onchocera volvulus adult ovary, $A$. suum embryo \& male testes ${ }^{\mathrm{a}}$ & 98 & ND \\
\hline $\begin{array}{l}14 \mathrm{e} 04-14 \mathrm{e} 06 / \\
\text { B }\end{array}$ & $\begin{array}{l}\text { Onchocera volvulus adult female; Alu repeat; EF-hand } \mathrm{Ca}^{2+} \text { binding } \\
\text { protein (putative) }\end{array}$ & 96 & ND \\
\hline \multicolumn{4}{|l|}{ Profile $C$} \\
\hline $1 \mathrm{~h} 07 / \mathrm{C}$ & Ascaris suum body wall-hypodermis ${ }^{\mathrm{a}}$ & 98 & ND \\
\hline $9 \mathrm{f} 10 / \mathrm{C}$ & $\begin{array}{l}\text { Ascaris suum adult muscle-nerve cord } \\
\text { (putative actin) }\end{array}$ & 99 & $\begin{array}{l}\mathrm{CE} 12358 ; 221 / 226 \text { aa } \\
\text { actin }\end{array}$ \\
\hline $7 \mathrm{e} 06 / \mathrm{C}$ & ND & ND & ND \\
\hline $10 \mathrm{f} 05 / \mathrm{C}$ & $\begin{array}{l}\text { Toxocara canis; } \\
\text { AJ } 306290 \text { myosin heavy chain }\end{array}$ & 86 & $\begin{array}{l}\text { CE09349; 68/124 aa } \\
\text { Myosin heavy chain }\end{array}$ \\
\hline $12 \mathrm{a} 10 / \mathrm{C}$ & Ascaris suum body wall-hypodermis ${ }^{\mathrm{a}}$ & 93 & ND \\
\hline
\end{tabular}


ducted to confirm the hybridization data where L4-21-J RNA was first labeled with $\mathrm{Cy} 5$ and all other samples with Cy3 for one hybridization, and then L4-21-J RNA was labeled with $\mathrm{Cy} 3$ and the other samples labeled with Cy5 for a second hybridization.

Differentially expressed cDNAs were sequenced automatically on an ABI Sequencer, model 3100, using vector-derived M13 primers. Data were subjected to a standard nucleotide-nucleotide search against the Nematoda database using WU-blastn. Open reading frames of selected clones also were translated and searched against the Welcome Trust Sanger Institute Caenorhabditis elegans Blast server. Both nucleotide and protein database searches are summarized in Table 1.

\section{Results}

\subsection{Differential gene expression between A. suum L4 isolated from pig jejunum versus ileum}

A cDNA microarray was constructed from mRNAderived L4-21-J to identify uniquely regulated sequences from L4 that survive host-induced spontaneous cure and are destined to develop into patent adult worms. Enzymatic amplification of 1920 clones indicated that $96 \%$ of the clones contained PCR products. Clones containing single amplicons $(93 \%)$ between 400 and 1500 bp in length were evaluated further. No effort was made to determine sequence redundancy among the clones tested. The critical comparison was between the homologous cDNA probe, L4-21-J, and the heterologous cDNA probe, L421-I, derived from two populations of L4 taken from the pig at the same time after inoculation but which segregated into the jejunum or the ileum (Fig. 1). Both populations were similar in size and actively migrated from the agar gel during the isolation procedure.

The first microarray hybridization analysis showed greater than twofold increases in the expression of 234 clones, and greater than twofold decreases in 25 other clones when normalized fluorescence signal intensities from the homologous L4-21-J and heterologous L4-21-I cDNA probes were compared. A total of 17 clones with no significant variation between replicate slides or between experiments was selected for further analysis and sequencing.

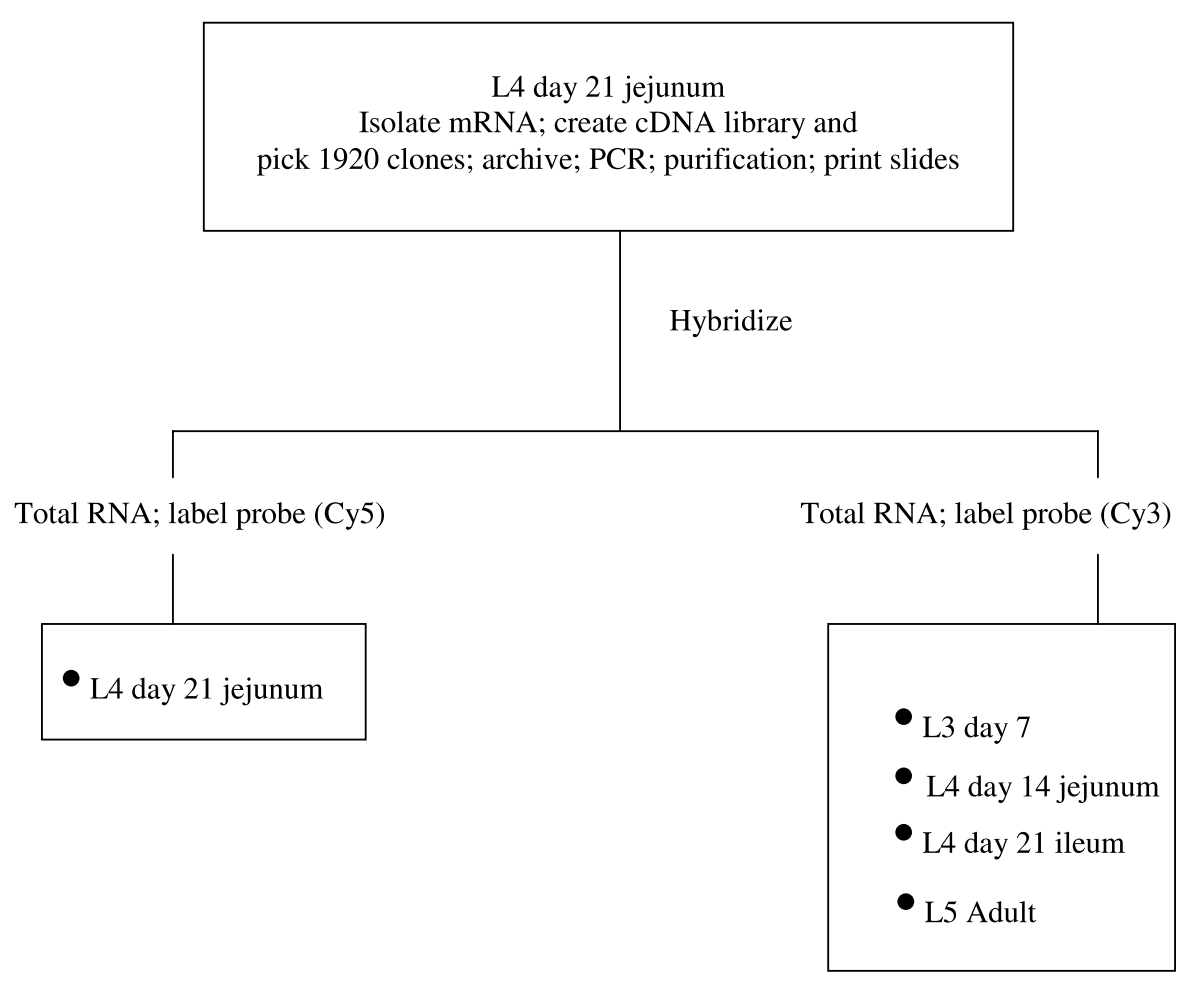

Fig. 1. Microarray flow-charts. cDNA library was constructed from L4 isolated from jejunum at 21 DAI (L4-21-J) mRNA and total RNA from the same stage was used as homologous control for hybridization. 1,920 clones were picked from the cDNA library, amplified by PCR, and 1776 of these clones with single amplicons of $400-1500 \mathrm{bp}$ were printed on the glass slides after purification. Fluorescent probes were prepared from total RNA that was isolated from: (1) L3 from lung at 7 DAI (L3), (2) L4 from jejunum at 14 DAI (L4-14-J), (3) L4 from jejunum at 21 DAI (L4-21-J), (4) L4 from ileum at 21 DAI (L4-21-I), and (5) L5 (adults). Total RNA from each stage was labeled using Cy3 or Cy5-dUTP. Reciprocal dye pairings were conducted to confirm the hybridization data where L4-21-J RNA was first labeled with Cy5 and all other samples with Cy3 for one hybridization, and then L4-21-J RNA was labeled with $\mathrm{Cy} 3$ and the other samples labeled with $\mathrm{Cy} 5$ for a second hybridization. The final fluorescence ratios were calculated by averaging data from three independent labeling and hybridizations from two sets of experiments. 
Co-hybridization of the microarray slides with cDNA probes from each of the developmental stages and with the L4-21-J cDNA produced three distinct patterns. Profile A (Fig. 2A) showed one group of clones where the transcription levels derived from L4-21-J cDNA were significantly elevated relative to all other stages as well as the segregated population of L4-21-I. In Profile B (Fig. 2B), a collection of 4 clones were identified that responded inversely to those depicted in Profile A, namely, all cDNA clones in Profile B were down-regu- lated in the L4-21-J stage compared to all other stages and the L4-21-I. However, these differences were less than twofold in magnitude. Clones depicted in Profile $\mathrm{C}$ (Fig. 2C) showed a more steady state level of expression between the L3, L4-14-J, L4-21-J, and L5 stages, but a markedly decreased level of expression in the segregated L4-21-I population.

Clones depicted in Profiles A, B, and C were partially sequenced and Blast searches were performed against the Nematoda database at the nucleotide level, and with
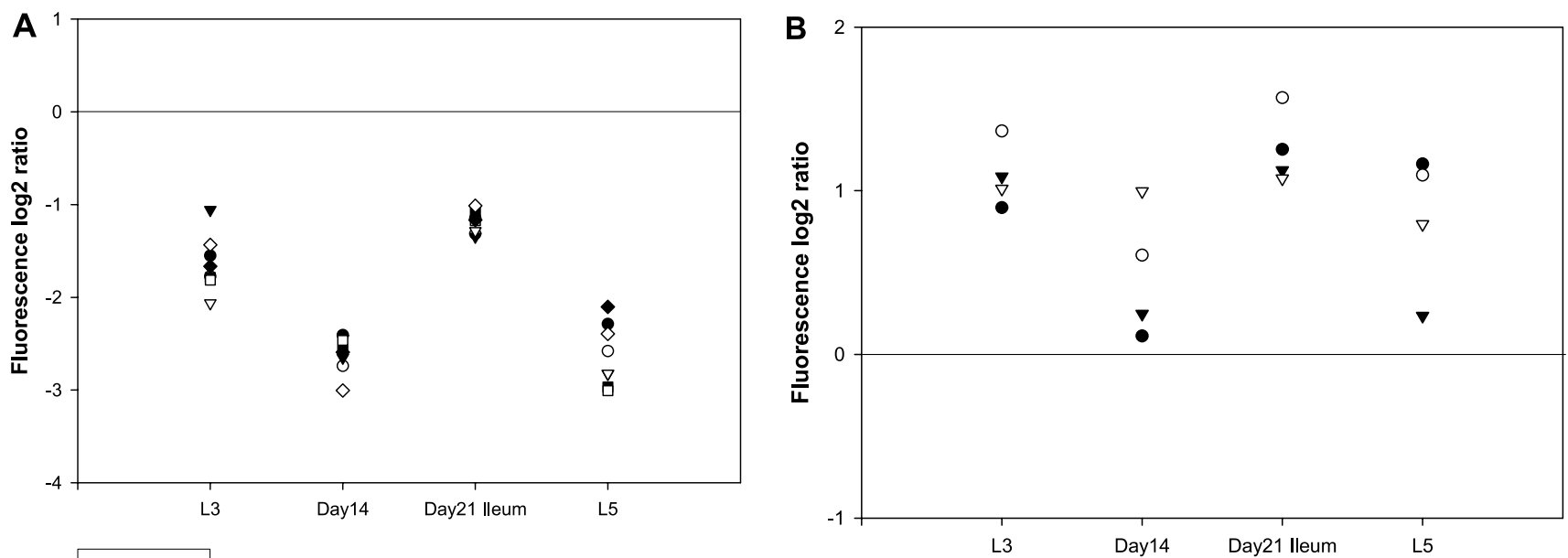

$\begin{array}{ll}\bullet & 2 \mathrm{~B} 10 \\ \circ & 3 \mathrm{~A} 01 \\ \nabla & 3 \mathrm{C} 03 \\ \nabla & 3 \mathrm{H} 08 \\ \mathbf{\square} & 7 \mathrm{E} 03 \\ \square & 8 \mathrm{~A} 08 \\ \bullet & 11 \mathrm{~A} 03 \\ \diamond & 13 \mathrm{H} 11\end{array}$
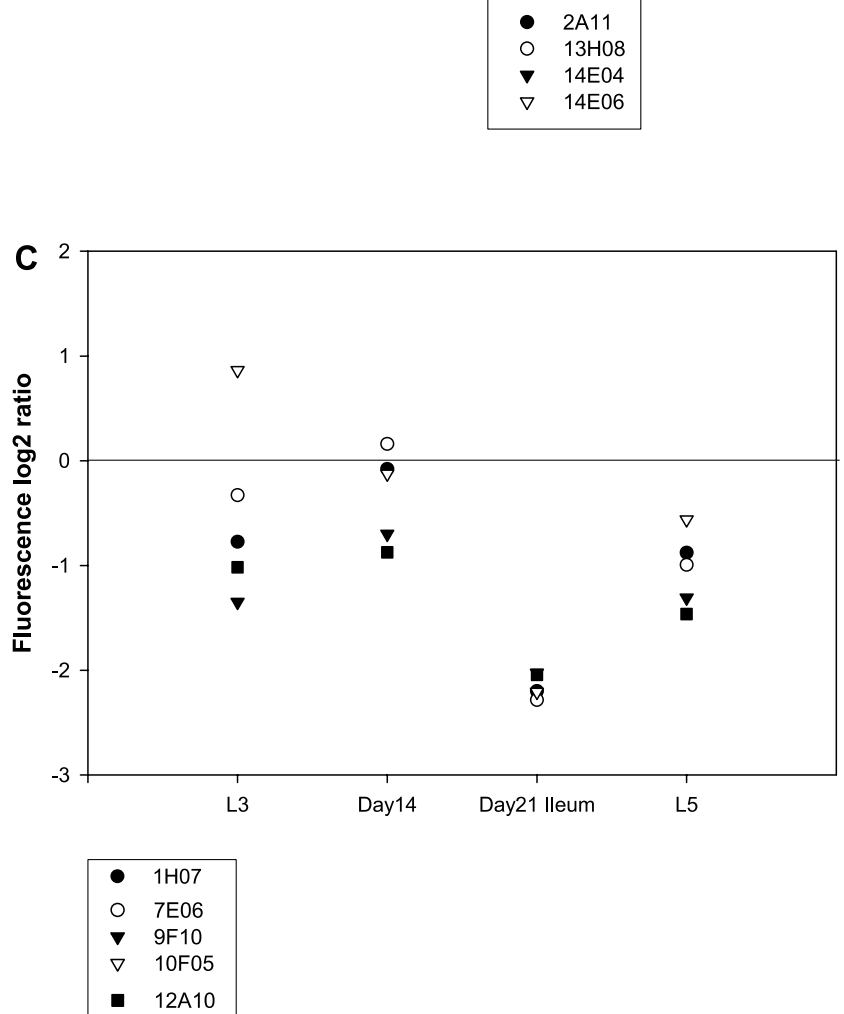

Fig. 2. Representative mRNA expression pattern from selected clones. Two image files (Cy3 and Cy5) generated by the scanner were analyzed using ScanAlyze. The results are depicted as $\log 2$ ratios of the fluorescence intensities comparing gene expression of the homologous L4-21-J stage (base line response of zero) to all other stages tested. (A) Eight clones that showed reduced expression compared to L4-21-J. (B) Four clones that showed increased gene expression compared to L4-21-J. (C) Five clones with gene expression similar to L4-21-J in all stages evaluated except L4-21-I. 
the $C$. elegans database at the level of translated protein (Table 1). Of those clones with $>90 \%$ DNA similarity to sequences in the nematode EST database, four (13h08/ $\mathrm{B}, 1 \mathrm{~h} 07 / \mathrm{C}, 12 \mathrm{a} 10 / \mathrm{C}$, and $8 \mathrm{a} 08$ ) matched sequences derived from an $A$. suum body wall-hypodermis cDNA library, and 3 of these were more highly expressed in L421-J than L4-21-I; the translated portion of $8 \mathrm{a} 08$ showed similarity to a $C$. elegans cuticular collagen. Clone (3a01) matched sequences for A. suum G3PDH and the C. elegans G3PDH protein, clone 3C03 matched $A$. suum ribosomal protein L11 sequences and the corresponding C. elegans protein, and clone $13 \mathrm{~h} 11$ matched the flavoprotein subunit of $A$. suum succinate dehydrogenase and the corresponding $C$. elegans protein. Clone 9f10/C is presumed to be $A$. suum muscle actin that corresponds to the $C$. elegans actin protein, while two others that missed the arbitrary $90 \%$ homology cut-off value, showed a high similarity (86\%) to myosin heavy chain from Toxocara canis and the heavy chain protein from C. elegans $(10 \mathrm{f} 05 / \mathrm{C})$, and to a troponin T-like protein found in the $C$. elegans protein database that corresponds to sequences from Onchocera volvulus (3H08). Profile B showed a reduced level of sequence expression from L4-21-J compared to L4-21-I for sequences derived from the $A$. suum body wall-hypodermis, A. suum embryo and male testes, and $O$. volvulus adult female cDNA library.

\section{Discussion}

Studies of nematode biology have been aided by the genomic sequence of the free-living nematode $C$. elegans that was completed in 1998; analysis of gene expression related to growth conditions, developmental stages and mutant strains using microarrays is available (Kim et al., 2001). In contrast, parasitic nematode genomics have been carried out largely through analysis of expressed sequence tag (EST) rather than full genome sequence, and there are now several lists of ESTs from parasitic nematodes of livestock and human, including Ascaris. Evaluating gene expression using cDNA microarray analysis allows for the simultaneous examination of a relatively large number of genes related to a particular biological event. Hybridization conditions that employ two-color fluorescent-labeled probes of a cDNA microarray can give rapid and simultaneous analysis of differential gene expression of two samples (Sharon et al., 1996) where relative amounts of transcription between the two samples are measured by comparing the intensity of fluorescent signals. Several formats have been described, but cDNA microarray has the advantage of representing active transcription of genes and provides an unbiased analysis of gene expression. Our objective was a proof of principle for the use of cDNA microarray to evaluate a discrete biological event related to the life cycle of $A$. suum and to characterize transcriptionally active genes related to parasitism based on currently available EST libraries.

Jones and Ogilvie (1971) initially characterized expulsion of a primary infection of Nippostrongylus brasiliensis from rats as an example of spontaneous cure of a gastrointestinal nematode parasite. Intestinal expulsion is not a lethal condition because worms can be rescued early in the expulsion process and transfer to a naïve host with normal resumption of development. Current interpretations of the events related to intestinal expulsion favor a role for a Th2 immune response with IL-4 and IL-13 particularly important in the induction of un-hospitable environment in the intestine that results in movement of the worm from its predilection site (Finkelman et al., 1997). These conditions are related to a 'weep and sweep' mechanism where type 2 cytokines alter the physiology of the intestine by increasing intestinal smooth muscle contractility, reducing epithelial cell glucose uptake and resistance, and creating a net increase in fluid accumulation in the intestine (Madden et al., 2002; Shea-Donohue et al., 2001). Gastrointestinal parasites, especially if not firmly attached to the intestinal mucosa, are forced from their feeding site in the intestine unless there is a counter action by the parasite to maintain its position. In fact, active worm counterregulation has been suggested from studies (Ishikawa et al., 1994), where $N$. brasiliensis adults obtained from the intestine of rats prior to expulsion inhibit the expulsion of a second population of 'antibody-damaged' worms that are destined to be expelled when both populations are concurrently transferred to a naïve host. The 'normal' worms apparently provided inhibitory signals that dampened the host's expulsion mechanism and prevents expulsion of the 'damaged' worms.

A spontaneous cure of $A$. suum $\mathrm{L} 4$ has been reported in swine given a single inoculation with different doses of infective eggs (Roepstorff et al., 1997). Most of the L4 that develop in the intestine at day 10 after inoculation are eliminated between days 17 and 21 resulting in a small aggregated population of larvae that continue to develop in the jejunum while the bulk of the L4 population is expelled. The Th2-derived cytokines that regulate intestinal immunity in rodents (Finkelman et al., 1997) have also been described in swine infected with $A$. suum (Ashraf et al., 1988; Dawson et al., 2003; Urban et al., 1988) including elevated reaginic antibody and intestinal mucosal mast cells (MMC) and eosinophilia. Although not definitive, the appearance of MMCs in $A$. suum-infected pigs that release histamine when exposed to A. suum L3 and L4 antigens (Ashraf et al., 1988), suggests that the 'weep and sweep' response that is partially MMC-dependent in rodents is expressed in pigs. In fact, the jejunum from pigs infected with $A$. suum exhibit changes in smooth muscle contractility and reduced epithelial cell resistance that are similar to those 
seen in mice infected with the gastrointestinal nematode Heligmosomoides polygyrus (Shea-Donohue et al., unpublished results). Therefore, sustained L4 parasitism in the pig intestine requires a mechanism to escape local host immunity. Our data revealed that L4s at 21 DAI are segregated into two populations that have differential gene expression. Both populations are viable and active because the isolation procedure from the intestine requires that they migrate free of a solid 1\% agar gel matrix in order to be collected for RNA extraction; the L4 from both the jejunum and ileum exhibited the rapid serpentine motion that is indicative of this stage. The L4 in the ileum, however, were unable to maintain their position in the jejunum. Consistent with this observation was the fact that the genes that showed the highest transcriptional activity in L4 from jejunum at 21 DAI compared to L4 from the ileum were specifically found within the EST library derived from body wall hypodermis and muscle tissue of $A$. suum and matched a $C$. elegans cuticle collagen, a troponin T-like protein, and actin and myosin heavy chain proteins. Vigorous motile activity and a metabolically active cuticular surface would be advantageous to larvae attempting to counter act an expulsive force. Thus, the relatively high level of expression in L4-21-J of sequences and putative proteins for the G3PDH (3a01), flavoprotein subunit for succinate dehydrogenase (13h11) and ribosomal protein L11 (3C03) represent highly conserved sequences for enzymes involved in glycolysis (Kasuga-Aoki et al., 2002), aerobic and anaerobic metabolism (Amino et al., 2000; Kuramochi et al., 1994) and protein synthesis (Van Dyke et al., 2002), respectively. It was also notable that transcription of genes derived from a testes germinal zone cDNA library were enhanced in the L4-21-J; the genital primordium becomes evident in L4 and has been used as a marker of L4 development in vivo and in vitro (Urban and Douvres, 1981). There was, however, increased expression of some un-annotated sequences from cDNA libraries derived from $A$. suum body wallhypodermis (13h08/B) and male testes (2a11/B) in L421-I compared to L4-21-J that suggests these are not absolute markers of larval longevity in the host. It is intriguing that two clone that were highly expressed in L4-21-I (14e04-06/B) are similar to the putative EF-hand $\mathrm{Ca}^{2+}$ binding protein that functions in the regulation of $\mathrm{Ca}^{2+}$-dependent cysteine proteases and apoptosis (Maki et al., 2002).

These results are consistent with the interpretation that specific gene expression of L4 in the jejunum can be a marker for successful parasitism and further worm development. There may be several explanations for selectively enhanced transcriptional regulation related to worm survival in the host. First, worms that arrive early in the jejunum escape the acquired immune response that is marked by increasing amounts of parasite-antigen specific reaginic antibody on an expanding popula- tion of MMCs (Ashraf et al., 1988). Second, only rapid and active worm development provides a population of robust worms able to survive a hostile microenvironment. Third, rapidly developing worms can successfully neutralize or counter act host protective responses. Distinguishing between these and other mechanisms can undoubtedly be a consequence of additional analysis of transcriptionally active genes. It would be advantageous to use new technologies like laser capture micro-dissection to isolate RNA from discrete L4-21 tissues that would be more relevant to regulation of development rather than using RNA isolated from whole larvae. The limitations of the current study were the relatively low number of genes analyzed compared to those that may be active in this stage of the parasite, the reference to an EST library that is incomplete, and the low sensitivity of the constructed microarray for detecting genes of low copy number that may be relevant to parasitism. Nevertheless, Ascaris-induced disease expression includes anorexia, organ distress, chronic inflammation, immediate-type hypersensitivity, poor weight gain and reduced cognitive development. A genomics based strategy to recognize novel vaccine targets or metabolic pathways that control worm development is a promising approach for the control of this important worm infection of both man and swine.

\section{Acknowledgments}

This work was supported under the United States Department of Agriculture, Agricultural Research Service, National Program in Animal Health (103), Human Nutrition (107), and Plant Biological and Molecular Processes (302), Cris Projects 1235-51000-044-00D and 1265-32000-064D and 1275-21220-098-00D, and from the Japan Society for the Promotion of Science (M. Morimoto).

\section{References}

Amino, H., Wang, H., Hirawake, H., Saruta, F., Mizuchi, D., Mineki, R., Shindo, N., Murayama, K., Takamiya, S., Aoki, T., Kojima, S., Kita, K., 2000. Stage-specific isoforms of Ascaris suum complex II: the fumarate reductase of the parasitic adult and the succinate dehydrogenase of free-living larvae share a common iron-sulfur subunit. Molecular Biochemistry and Parasitology 106, 63-76.

Ashraf, M., Urban Jr., J.F., Lee, T.D.G., Lee, C.M., 1988. Characterization of isolated porcine intestinal mucosal mast cells following infection with Ascaris suum. Veterinary Parasitology 29, 143 158.

Bigger, C.B., Brasky, K.M., Lanford, R.E., 2001. DNA Microarray analysis of chimpanzee liver during acute resolving hepatitis $\mathrm{C}$ virus infection. Journal of Virology 75, 7059-7066.

Chan, M.S., 1997. The global burden of intestinal nematode infections: fifty years on. Parasitology Today 13, 438-443.

Chang, Y.E., Laimins, L.A., 2000. Microarray analysis identifies interferon-inducible genes and Stat-1 as major transcriptional 
targets of human papillomavirus type31. Journal of Virology 74 , 4174-4182.

Dawson, H.D., Beshah, E., Nishii, S., Solano-Aguilar, G., Morimoto, M., Zhao, A., Madden, K.B., Ledbetter, T.K., Dubey, J.P., SheaDonohue, T., Lunney, J.K., Urban Jr., J.F., 2003. Localized multigene expression patterns support an evolving Th1/Th2 paradigm in response to infections with Toxoplasma gondii and Ascaris suum in pigs. Journal of Immunology (submitted).

Douvres, F.W., Tromba, F.G., Malakatis, G.M., 1969. Morphogenesis and migration of Ascaris suum larvae developing to fourth stage in swine. Journal of Parasitology 55, 689-712.

Eriksen, L., Lind, P., Nansen, P., Roepstorff, A., Urban Jr., J.F., 1992. Resistance to Ascaris suum in parasite naïve and naturally exposed growers finishers and sows. Veterinary Parasitology 41, 137-149.

Fagerholm, H.P., Nansen, P., Roepstorff, A., Frandsen, F., Eriksen, L., 2000. Differentiation of cuticular structures during the growth of the third-stage larva of Ascaris suum (Nematoda, Ascaridoidea) after emerging from the egg. Journal of Parasitology 86, 421-427.

Finkelman, F., Shea-Donohue, T., Goldhill, J., Sullivan, C., Morris, S., Madden, K., Gause, W., Urban Jr., J.F., 1997. Cytokine regulation of host defense against parasitic GI nematodes: lessons from studies with rodent models. Annual Reviews in Immunology $15,505-533$.

Geiss, G.K., Bumgarner, R.E., An, M.C., Agy, M.B., van’t Wout, A.B., Hammersmark, E., Carter, V.S., Upchurch, D., Mullins, J.I., Katze, M.G., 2000. Large-scale monitoring of host cell gene expression during HIV-1 infection using cDNA microarrays. Virology 266, 8-16.

Hegde, P., Qi, R., Abernathy, K., Gay, C., Dharap, S., Gaspard, R., Earle-Hughes, J., Snesrud, E., Lee, N., Quackenbush, J., 2000. A concise guide to cDNA microarray analysis. Biotechniques 29, $548-562$.

Ishikawa, N., Horii, Y., Nawa, Y., 1994. Inhibitory effects of concurrently present 'normal' Nippostrongylus brasiliensis worms on expulsion of 'damaged' worms and associated goblet cell changes in rats. Parasite Immunology 16, 329-332.

Jones, V.E., Ogilvie, B.M., 1971. Protective immunity to Nippostrongylus brasiliensis: the sequence of events which expels worms from the rat intestine. Immunology 20, 549-561.

Kasuga-Aoki, H., Tsuji, N., Suzuki, K., Matsumoto, Y., Arakawa, T., Isobe, T., 2002. Molecular characterization of a glyceraldehydes-3phosphate dehydrogenase from the swine roundworm Ascaris suum. Molecular Biochemistry and Parasitology 119, 135-139.

Kim, S.K., Lund, J., Kiraly, M., Duke, K., Jiang, M., Stuart, J.M., Eizinger, A., Wylie, B.N., Davidson, G.S., 2001. A gene expression map for Caenorhabditis elegans. Science 293, 2087-2092.

Kuramochi, T., Hirawake, H., Kojima, S., Takamiya, S., Furushima, R., Aoki, T., Komuniecki, R., Kita, K., 1994. Sequence comparison between the flavoprotein subunit of the fumarate reductase (complex II) of the anaerobic parasitic nematode, Ascaris suum and the succinate dehydrogenase of the aerobic, free-living nematode, Caenorhabditis elegans. Molecular and Biochemical Parasitology 68, 177-187.
Madden, K.B., Whitman, L., Sullivan, C., Gause, W.C., Donaldson, D.D., Urban Jr., J.F., Katona, I.M., Finkelman, F.D., SheaDonohue, T., 2002. Role of Stat6 and mast cells in IL-4 and IL-13induced alterations in murine intestinal epithelial cell function. Journal of Immunology 168, 4417-4422.

Maki, M., Kitaura, Y., Satoh, H., Ohkouchi, S., Shibata, H., 2002. Structures, functions and molecular evolution of the penta-EFhadn $\mathrm{Ca}^{2+}$-binding proteins. Biochimca Biophysica Acta 1600, 5160.

Murrell, K.D., Eriksen, L., Nanen, P., Slotved, H.C., Rasmussen, T., 1997. Ascaris suum: revision of its early migratory path and implication for human ascariasis. Journal of Parasitology 83, 255 260.

Pilitt, P.A., Lichtenfels, J.R., Tromba, F.G., Madden, P.A., 1981. Differentiation of late fourth and early fifth stages of Ascaris suum Goeze, 1782 (Nematoda: Ascaridoidea) in swine. Proceedings of the Helminthological Society of Washington 48, 1-7.

Roepstorff, A., Eriksen, L., Slotved, H.C., Nansen, P., 1997. Experimental Ascaris suum infection in the pig: worm population kinetics following single inoculations with three doses of infective eggs. Parasitology 115, 443-452.

Roepstorff, A., Nansen, P., 1998. The epidemiology, diagnosis and control of helminth parasites in swine. A FAO Handbook, FAO Rome.

Sharon, D., Smith, S.J., Brown, P.O., 1996. A DNA microarray system for analyzing complex DNA samples using two- color fluorescent probe hybridization. Genome Research 6, 639-645.

Shea-Donohue, T., Sullivan, C., Finkelman, F.D., Madden, K.B., Morris, S.C., Goldhill, J., Pineiro-Carrero, V., Urban Jr., J.F., 2001. The role of IL-4 in Heligmosomoides polygyrus-induced alterations in murine intestinal epithelial cell function. Journal of Immunology 167, 2234-2239.

Slotved, H.C., Barnes, E.H., Eriksen, L., Roepstorff, A., Nansen, P., Bjorn, H., 1997. Use of an agar-gel technique for large scale application to recover Ascaris suum larvae from the intestinal contents of pigs. Acta Veterinaria Scandinavia 38, 207-212.

Urban Jr., J.F., 1993. Acquired immunity to the nematode parasites of major economic importance in swine. Compendium (Continuing Education for the Practicing Veterinarian) 15, 1297-1312.

Urban Jr., J.F., Alizadeh, H., Romanowski, R.D., 1988. Ascaris suum: development of intestinal immunity to infective second-stage larvae in swine. Experimental Parasitology 66, 66-77.

Urban Jr., J.F., Douvres, F.W., 1981. In vitro development of Ascaris suum from 3rd to 4th-stage larvae and detection of metabolic antigens in multi-well cultures systems. Journal of Parasitology 67, 800-806.

Urban Jr., J.F., Romanowski, R.D., 1985. Ascaris suum: protective immunity in pigs immunized with products from eggs and larvae. Experimental Parasitology 60, 245-254.

Van Dyke, N., Xu, W., Murgola, E.J., 2002. Limitation of ribosomal protein L11 availability in vivo affects translation termination. Journal of Molecular Biology 319, 329-339. 